\title{
Mobile Learning for Colleges of Education in Nigeria: An Educational Analysis
}

\author{
John G. Chaka \\ PhD candidate at University of KwaZulu-Natal \\ Email: chakajohn@yahoo.com
}

Irene Govender

Discipline of Information System and Technology, University of KwaZulu-Natal

Email: Govenderi4@ukzn.ac.za

\section{Doi:10.5901/mjss.2014.v5n16p289}

\section{Abstract}

\begin{abstract}
The world has passed through different phases of technology enhanced learning ranging from distance learning to mobile learning, an extension of e-learning. Currently, attention is drawn towards location-aware, context-aware and ubiquitous learning systems. The slow pace of development in Nigeria has hindered technologically enhanced learning in institutions of higher learning. The purpose of this paper was to assess the status of mobile learning in institutions of higher learning in Nigeria. The study adopted a theoretical approach by reviewing the possibilities and applications of Mobile Learning System globally and in particular Nigeria. The review showed that despite the huge success stories that have been recorded in the application of mobile learning across the world, the situation is different in Nigeria - as the literature indicated little success in this direction. More specifically no evidence of application or adoption of mobile learning in Colleges of Education in Nigeria could be established from the literature. The study concluded that with the emergence of new learning systems, there is need to conduct an in-depth study, to ascertain the feasibility of developing a model for implementing mobile learning in Colleges of Education in Nigeria.
\end{abstract}

Keywords: Colleges of Education, Technology Enhanced Learning, Mobile learning.

\section{Introduction}

According to the Yaradua Foundation Report (2013) an estimated 26 million Nigerian youth have little access to tertiary education and the difficulty in sustaining education through traditional means in higher education institutions prevails (Adu, Eze, Salako \& Eyangechi, 2013). These youth are therefore considered unemployable. This situation is attributed to a high population growth, escalating demand for education, inadequate funding and the difficulty in delivering education through traditional methods. The report further states that the higher education institutions in Nigeria, together, have an approximate enrolment capacity of two million students and that poor access to formal education has therefore resulted in a high dropout rate. In addition, Clark and Ausukuya (2013) state that the needed human resources (teacher student ratio as high as 1:356 in some cases) are inadequate, indicating the inability of existing structures (classrooms, learning and human resources) to cope with the growing population through traditional learning practices. These problems cut across all tertiary institutions in Nigeria including Colleges of Education (Kwache, 2007).

According to Olakulehin (2007), the mandate for Colleges of Education is to provide highly motivated, conscientious and efficient classroom teachers; and to further encourage the spirit of enquiry and creativity in teachers in order to help them fit into the social life of the community and society at large. By following this mandate, it is expected to enhance their commitment to the teaching profession. Imam (2012, p.193) reaffirmed this commitment to quality education by amending the policy to state that "... the minimum standard for entry into the teaching profession was raised from Teacher Grade II Certificate to the National Certificate of Education (NCE)". This commitment was acknowledged in the report of the steering committee of the Federal Republic of Nigeria and the International Labour Organisation,(FRN and ILO,2005, p.14), which states in part that: 
According to Haddad (2007), quality education presupposes development of high quality teachers. If this is true, the implication therefore is that, if the teacher is underprepared, then the entire nation is at a cross road. Unfortunately, while the number of in-service teachers in Nigerian schools is grossly inadequate, and the number of students seeking admission into higher institutions is escalating, the structures, facilities and learning system in the Colleges of Education cannot meet these challenges (Kwache, 2007). The required human resources, classroom infrastructure and learning materials are inadequate, resulting in further reducing student enrolments. For Nigeria to move forward in education, the learning system in these institutions must be reviewed with a view to change.

A number of attempts have been made to address the problems, but not at the level of colleges of education. Since education, specifically teacher education holds the key to the sustainable development of any nation (Babatunde \& Ogedebe, 2012), a timely intervention will go a long way in repositioning Nigeria towards attaining national and global objectives. Ogboru (2008) posits that the solution lies in exploring the possibility of utilizing global knowledge to handle local problems through investing in human capital and appropriate integration of technology. This study therefore explores the viability of mobile learning to complement the traditional learning practices in Colleges of Education in Nigeria. The importance of a learning environment (Hemabala \& Suresh, 2012) and ease of access to learning resources (Rieber, 2001) have been highlighted. One way of resuscitating the status of colleges of education and lifting the quality of their products is by improving the learning environment and access to learning resources. We therefore ask the following research questions:

- What is a learning environment?

- How can access to learning resources in the environment be improved?

- How can learning be improved?

\subsection{Learning Environment}

A learning environment consists of a place and tools that are used to support a learning process, which no doubt influences or determines the learning system or method. Rieber (2001) sees a learning environment as a place that has resources, time, and reasons to enable people to nurture and value their learning experiences and ideas. He maintains that the ability to access learning resources in the environment is vital. Similarly, Warger, Serve and Dobbing (2009) claim that a learning environment include learning resources, technology, and the ways in which teaching and learning takes place in relation to societal and global perspectives.

It is common knowledge that a large proportion of what we know today has been gained from our surroundings and experiences. Therefore a learning environment contributes either positively or negatively to learning in the same way that our environment does to our lives. As mentioned earlier, in as much as the learning resources are crucial, the ability to access the resources is even more crucial.

\subsection{Improving access to learning resources}

Several studies (for example Warger, Serve \& Dobbing, 2009; Ayanda, Eludiora, Amassoma \& Ashiru, 2011) claim that the introduction of technology is one way of improving access to learning resources. This can be done through the use of learning management systems (LMS) and other learning technologies. Trayek and Hassan (2013) perceive a learning management system as a platform which eases communication among students and teachers and also help students to complete their activities such as uploading documents and having access to information anytime and anywhere as quickly as possible. Similarly, Gudanescu (2012) concurs that using LMS in education will make access to the learning content easier for students and teachers.

With the increase in penetration and versatility of mobile devices, several studies (for example, Ayanda et al., 2011; Trayek \&Hassan, 2013) argue that an increase in the penetration of mobile phone networks, the multimedia capabilities embedded in phones and Web 2.0 Internet technology have positioned mobile devices for effective learning. Warschauer (2011) enumerates some advantages of using mobile devices in education namely easy reading; fast switching ability among applications; touch screen interface which provides friendly user interactivity; easy mobility and affordable application development. Against this backdrop, Technology enhanced learning (TEL) is shifting towards mobile learning. 


\section{Viability of Mobile Learning System}

\subsection{Mobile learning system across the globe}

A large and growing body of literature (for example Warschauer, 2011; Ako-Nai \& Tan, 2013; Mogire and Oboko, 2013) has investigated the integration of mobile learning systems. In a major study, involving three countries namely, Italy, Sweden and UK, Attewell and Saint-Smith (2004) investigated young adults usage of mobile phones to predict the future usage of mobile devices and to determine the willingness of these young adults in using mobile devices for learning purposes. Their results revealed that $49 \%$ of the sample showed interest in using phone-based games to improve spellings and reading and $44 \%$ indicated same for mathematics. Similarly, Kumar, Tewari, Shroff, Chittamuru, Kam and Canny (2010) investigated the extent to which children were willing to use mobile phones to access learning content. Likewise, their results showed a positive level of learning and motivation.

Donner (2009) reviewed the impact of mobile devices on education in developing countries, specifically Tanzania and Thailand. His study revealed that attitudes towards the use of mobile devices for learning were positive. In another, but related study, Warschauer (2011) investigated the use of iPads in K-12 schools in the United States, revealing among other findings that iPads were preferred to laptops in view of their light weight, portability, touch screen, and user friendly applications. Similarly, Valk, Rashid and Elder (2010) examined the extent to which the use of mobile phones can assist to improve access to educational resources and promote acquisition of knew knowledge. Having reviewed the results of some pilot projects from Asia, Philippines, Mongolia, Thailand, India, and Bangladesh, it was concluded that while mobile phones had a huge impact in the facilitation of increasing access to education, there was little evidence in promoting new learning.

Based on the viability of mobile devices for learning, Tan, Zhang, Kinshuk and Mcgreal (2011) proposed a framework for adaptive location-based mobile learning using the semantic technology and ontology-based method aimed at providing the right content to the right learner at the right time and right location using the right device. In other words, the framework revealed that time, location, learner and device are determinants of the right content, which ultimately is the objective of the system. Based on aspects of this framework, Ako-Nai and Tan (2013) implemented a Learning Management System for Adaptive Mobile Learning. Their study revealed a number of differences namely:

1. Students were more engaged when using mobile devices and game-based learning approaches for studying.

2. Ownership and collaboration improved significantly with students in the mobile learning and game-based environment.

3. Student learning and collaborative knowledge building improved as it was evident that the use of mobile devices and location game-based learning also promotes and enhances collaborative learning and builds learning communities.

Concerned by the challenges that learners face on the web before obtaining the right content at the right time and location, and the lack of desired collaboration by students, Mogire and Oboko (2013) proposed a framework to support ubiquitous formal learning using Mashups (interactive web applications which combines learning content from various sources). This framework, which took context awareness and collaboration into account, consists of components that access websites to develop content from diverse sources - to match users' devices, no matter their locations. One advantage of their framework is the fact that its design took a formal learning environment into account.

\subsection{Mobile learning system in Nigeria}

There are numerous (106) federal, state and privately own universities in Nigeria (Ahmad, Chinada, Gambaki, Ibrahim \& Ala, 2012), but few employ learning management systems or implement a viable e-learning system. They therefore advocate the adoption of Moodle by Nigerian Higher Education Institutions (HEls), specifying that Moodle has the appropriate tools to manage and promote learning in addition to its scalability, support for blended learning, and the fact that it can be customised to suit the users.

In another but related study, Liverpool, Marut, Ndam and Oti (2010) proposed a model for the integration of elearning in Higher Education Institutions based on the experiences of the ICT-Maths initiative in the University of Jos. The proposed model which used Moodle as the LMS consisted of two phases: one for the pre-project activities and the second for the implementation processes. Similarly, Ayanda et al. (2011) developed an e-learning model using an evolutionary software approach. Due to the high cost of computers and internet bandwidth, these two models had a small impact on learning itself (Madu and Pam, 2011). In view of this Adedoja, Botha and Ogunleye (2012) support mobile 
learning as a better alternative to the e-learning model proposed above.

In order to ascertain the status of mobile learning in Nigeria, it is necessary to determine the status of mobile infrastructure in the country. The results published by Pyramid Research (2010) revealed that mobile services were in use by a significant proportion of Nigeria's population. They estimated the number of mobile subscriptions in the country to be 73 million resulting in a mobile penetration rate of $49 \%$ of the population. It was therefore suggested that due to intense competition and constant innovation from mobile service providers, a greater number of people would realize its value and be well positioned to make use of the full potential of mobile services in the near future. However, Pyramid research (2010) claimed that the adoption rate of mobile learning was very low.

Subsequently, Utulu and Alonge (2012) investigated the use of mobile phones for Project Based Learning (PBL) among privately own universities in the south west zone of Nigeria. It was shown that $95.9 \%$ (based on tables one and two below) of the respondents possessed mobile phones, which they used for communication, interactions, obtaining information, browsing the Internet, and sharing knowledge when they were involved in PBL - while $2.3 \%$ had no phones and $0.8 \%$ had lost their phones. It can be inferred that mobile phones are viable in strengthening PBL as well as in implementing information services in the institutions. Tables one and two below indicate the various applications that are present in the respondents' mobile phones and the frequency of use of the applications during PBL respectively.

Table1: Distribution of mobile phone applications available in respondents' mobile phone

\begin{tabular}{|c|l|c|c|}
\hline S/N & Mobile Phone Services & Number & Percentage \\
\hline 1. & Voice Calls & 532 & 100 \\
\hline 2. & Short Message Service (SMS) & 532 & 100 \\
\hline 3. & Internet Services & 412 & 77.4 \\
\hline 4. & Multimedia Message Service (MMS) & 411 & 77.3 \\
\hline 5. & Camera (Images and Videos) & 401 & 75.4 \\
\hline 6. & Radio & 386 & 72.6 \\
\hline 7. & Voice Mail & 385 & 72.4 \\
\hline 8. & Audio Recording & 371 & 69.7 \\
\hline 9. & Television (TV) & 80 & 15.0 \\
\hline
\end{tabular}

Utulu and Alonge (2012:9)

Table2: Respondents' self- assessment of the frequency of their use of available mobile phone application

\begin{tabular}{|l|c|c|c|c|c|c|c|c|c|c|c|c|c|c|}
\hline Mobile phone Service & \multicolumn{2}{|c|}{ Very Often } & \multicolumn{2}{|c|}{ Often } & \multicolumn{2}{c|}{ Not Sure } & \multicolumn{2}{c|}{ Not Often } & \multicolumn{2}{c|}{ Not Very Often } & \multicolumn{2}{|c|}{ Not At All } & \multicolumn{2}{|c|}{ Ro Response } \\
\hline & No. & $\%$ & No. & $\%$ & No. & $\%$ & No. & $\%$ & No. & $\%$ & No. & $\%$ & No. & $\%$ \\
\hline Voice Calls & 240 & 45.1 & 90 & 16.9 & 24 & 4.5 & 66 & 12.4 & 22 & 4.1 & 87 & 16.4 & 3 & 0.6 \\
\hline SMS & 274 & 51.5 & 139 & 26.1 & 15 & 2.8 & 31 & 5.8 & 25 & 4.7 & 45 & 8.5 & 3 & 0.6 \\
\hline MMS & 58 & 10.9 & 75 & 14.1 & 41 & 7.7 & 98 & 18.4 & 55 & 10.3 & 198 & 37.2 & 7 & 1.4 \\
\hline Voice Mail & 58 & 10.9 & 40 & 7.5 & 32 & 6.0 & 81 & 15.2 & 50 & 9.4 & 266 & 50.0 & 5 & 1.0 \\
\hline Internet Service & 202 & 38.0 & 94 & 17.7 & 25 & 4.7 & 39 & 7.3 & 26 & 4.9 & 141 & 26.5 & 5 & 1.0 \\
\hline Radio & 115 & 21.6 & 98 & 18.4 & 23 & 4.3 & 42 & 7.9 & 32 & 6.0 & 216 & 40.6 & 6 & 1.2 \\
\hline TV & 39 & 7.3 & 61 & 11.5 & 9 & 1.7 & 41 & 7.7 & 20 & 3.8 & 356 & 66.9 & 6 & 1.2 \\
\hline Audio Recording & 101 & 19.0 & 80 & 15.0 & 34 & 6.4 & 71 & 13.3 & 35 & 6.6 & 205 & 38.5 & 6 & 1.2 \\
\hline Video Recording & 119 & 22.4 & 82 & 15.4 & 44 & 8.3 & 55 & 10.3 & 34 & 6.4 & 193 & 36.3 & 5 & 1.0 \\
\hline Camera & 153 & 28.8 & 76 & 14.3 & 21 & 3.9 & 30 & 5.6 & 31 & 5.8 & 216 & 40.6 & 5 & 1.0 \\
\hline
\end{tabular}

Utulu and Alonge (2012:10)

Ogbuju, Mbanusi, Chukwu and Onyesolu (2012) developed a mobile learning framework for students of Nnamdi Azikiwe University. They claimed that the system could enable students to access academic content, submit assignments remotely, access resources in the library, and collaborate with each other via the system.

Other attempts which are being made towards the integration of mobile learning in Nigeria include Jamb mobile (Adedoja, Botha \& Ogunleye, 2012), which is an initiative of the Joint Admissions and Matriculation Board and that of the university of Ibadan. These attempts are made towards improving access to learning materials for preparation of examinations and to improve teaching and learning in the university. Although these initiatives are laudable, they targeted 
only Universities, with the exception of the Jamb mobile.

The research to date has tended to focus on universities to the exclusion of colleges of education indicating that the integration of ICT in teacher education is lagging behind by far (Tella, 2011). Tella's (2010) research, which ascertains the state and use of ICT facilities in Colleges of Education in the South West zone of Nigeria, reveals that only $12.5 \%$ of the institutions studied had internet connectivity while just $25 \%$ of them use the available ICT facilities for research and learning. For this reason, Wokocha and Adebayo (2012) proposed a guide for establishing Management Information Systems in Colleges of Education. The guide includes components such as input design, output design, data storage facilities, data warehouse, data risk management, and testing.

\section{Findings and Discussions}

The literature has clearly established that mobile learning is viable and fast gaining grounds across the globe but its adoption rate in Nigeria is slow. Although the efforts of Utulu and Alonge (2012), Ogbuju et al. (2012) and Adedoja, Botha and Ogunleye (2012) are commendable, they all aimed at introducing mobile learning at the university level of education. Colleges of Education have their peculiar learning environments and objectives but no effort has been made towards ascertaining the viability and possibly the adoption of mobile learning to address the problems that are hampering the effective attainment of their objectives. Tella (2011, pp. 318-319) affirmed this as he states that "though we heard of elearning of recent, but its awareness and/or efficacy in Colleges of Education is seriously in doubt." While this study concurs with Ogbuju et al. (2012) in finding or developing a technology enhanced learning system for Nigerian institutions, it further advocates a system that takes cognisance of the users. The system must be tailored to the peculiarities of the user's environment as the user (Harris and Weistroffer, 2008) plays a vital role in the success of any project. This can be achieved by gathering pertinent information regarding the operating environment, preferences, attitude towards change and associated challenges such as cost and access to technology on the part of the user and other stakeholders. This calls for a more practical approach to gathering data rather than theoretical. The main limitation of the research and results contained in the Yardaua Foundation report (2013), however, is that it does not take into consideration the formal learning setting, which is different from informal learning. This suggests that the content of the report may not be applicable to the peculiarities of a formal learning system, which has defined structures, rules and procedures.

In Nigeria, Colleges of Education are considered to be in the middle-level of higher institutions in the country, and they are responsible for training and educating teachers. The mandate of Colleges of Education (Olakulehin, 2007) is to provide and train high quality and efficient classroom teachers, inculcating the spirit of enquiry and innovation in teachers and most importantly instilling skills, a sense of commitment and motivation in teachers towards the teaching profession. For this reason, much is really expected from Colleges of Education. Therefore, it is of paramount importance that Colleges of Education in Nigeria are at the forefront of teaching and learning, given that these institutions are responsible for teacher education. However, no effort towards developing any form of technology enhanced learning system has been made at the level of Colleges of Education. The inadequacies of the previous studies justify the interest and significance of this study.

\section{Conclusion and Way Forward}

This article has given an account of the widespread use of mobile technologies and its use for learning. Despite its exploratory nature, this study offers some insight into the state of ICT integration in Nigeria. It has been inferred that ICT integration in teaching and learning involving mobile phones, is no longer a distant concept. Ardila (2013) points out that the world has in recent years witnessed an increase in the market of handheld and mobile technologies, which has drawn the attention of researchers to Technology Enhanced Learning (TEL).

The viability of mobile learning in different parts of the world, specifically the developed countries (Valk et al. 2010) is evident. This evidence has resulted in the metamorphosis of learning systems from paper-based distance learning to elearning, extending to mobile learning with emerging learning technologies such as location-ware, context-aware and ubiquitous learning - all becoming key elements of national information technology strategies in many countries today (Wen, Cheng, Chen, and Hsieh, 2013). Thus, the need to explore the possibility of tailoring this learning to the local environment in Nigeria (Traxler, 2011) remains pertinent. As pointed out by Cobcroft, Towers, Smith, and Bruns (2006), key questions that will require answers with particular reference to emerging learning systems in Colleges of Education in Nigeria include:

- Are there policy provisions in support of mobile learning in Nigeria? 
- Do the institutional management support mobile learning?

- What about ethical issues? For example, will the adoption of technology enhanced learning fall in line with the quest of the Nigerian government to promote the reading culture of students?

- How can mobile learning be integrated into the learning process of Colleges of Education in Nigeria to address the prevailing problems of inadequacy of classrooms, manpower and learning resources?

- Can the quality of service provided by telecommunication companies in Nigeria guarantee the adoption of mobile learning?

These and many other issues need to be ascertained to guide the appropriate implementation of a mobile learning system in Nigeria. It must be emphasised that Nigeria can no more remain in the perimeter of enhanced learning systems with only a small population gaining access to educational resources and institutions. Based on the results of the literature review of mobile learning systems in Nigeria, it is the position of this research to conduct a feasibility study for the implementation of a mobile learning system in Nigerian institutions, specifically the Colleges of Education. This research will require first-hand information from the field, with a view to developing a practical mobile learning model. It is recommended that the implementation and evaluation of the emerging learning system be further investigated from the Nigerian perspective.

\section{References}

Adedoja, G., Botha, A., \& Ogunleye, O. S. (2012). The future of mobile learning in the Nigerian education system. IST-Africa 2012 Conference Proceedings, Pretoria: IIMC International Information Management Corporation, 1-8.

Adu, E.O., Eze, I.R., Salako, E.T. \& Nyangechi, J. M. (2013). E-learning and distance education in Nigeria. International Journal of Science and Technology, 2 (2), 203-210.

Ahmad, S.A., Chinade, U. B., Gambaki, A. M., Ibrahim, S. \& Ala, N. N. (2012). The need for moodle as a learning management system in Nigerian universities: Digesting university Utara Malaysia learning zone as a case study. Academic Research International, 2(3), 444-458.

Ako-Nai, F. \& Tan, Q. (2013). Location-based learning management system for adaptive mobile learning. International Journal of Information and Education Technology, 3(5), 529-535.

Ardila, S. E. G. (2013). Learning design implementation in contex-aware and adaptive mobile learning. [Online] Available: http://hdl.handle.net (September 2, 2013).

Attewell, J. \& Savill-Smith, C. (2004). Mobile learning and social inclusion: focusing on learners and learning. In Attewll, J. \& Savill-Smith, C.(Eds.). Learning with mobile devices research and development. London: Learning and skills development agency, 3-11.

Ayanda, D., Eludiora, S., Amassoma, D. \& Ashiru, M. (2011).Towards a model of e- learning in Nigerian higher institutions: an evolutionary software modelling approach. [Online] Available: www.iiste.org (August 24, 2013).

Babatunde, P.J. \& Ogedebe, P.M. (2012). Information technology as a tool for realizing the Nigerian vision 2020. Academic Research International, 2(3), 562-570, May.

Clark, N. and Ausukuya, C. (2013). An overview of education in Nigeria. World Education News and Reviews. [Online] Available: http://wenr.wes.org/2013/07/an-overview-of- education-in-nigeria (October 25, 2013).

Cobcroft, R., Towers, S., Smith, J. \& Bruns, A. (2006). Mobile learning in review: opportunities and challenges for learners, teachers, and institutions. In Proceedings Online Learning and Teaching (OLT) Conference. Brisbane: Queensland University of Technology, 21-30.

Donner, J. (2009). Research approaches to mobile use in the developing world: A review of the literature in the information society. The Information Society Journal, 24(3), 140-159.

Federal Republic of Nigeria \& International Labour Organisation (2005). Teachers for the future: meeting teacher shortages to achieve education for all: action programme on education. [Online] Available: http://www.lo.org/wcmsp5 (September 13, 2013).

Gudanescu, N. (2012). E-Learning in higher and adult education.[Online] Available: www.intechopen.com (August 23, 2013).

Haddad, G. (2007). Welcome address in teacher policy forum for Sub-Saharan Africa. [Online] Available: http:/lunesdoc.unesco.org (April 8, 2009).

Harris, M. A. \& Weistroffer, H. R. (2008). Does the user participation lead to system success? [Online] Available: www.sais.aisnet.org (September, 10, 2013).

Hemabala, J. \& Suresh, E.S.M. (2012). The framework design of mobile learning management system. International Journal of Computer and Information Technology, 1(2), 179-184.

Imam, H. (2012). Educational Policy in Nigeria from the colonial era to the post- independence period. Italian Journal of Sociology of Education, 1, 181-204.

Kumar, A., Tewari, A., Shroff, G., Chittamuru, D., Kam, M., \& Canny, J. (2010). An exploratory study of unsupervised mobile learning in rural India. [Online] Available: http://bid.berkeley.edu (September 09, 2013).

Kwache, P.Z. (2007). The imperative of information and communication technology for teachers in Nigeria higher education. Journal of Online Learning and Teaching, 3(4), 395-398.

Liverpool, L.S.S., Marut, M.J., Ndam, J.N. \& Oti, D.A.. (2010). Towards a model for e- learning in Nigerian HEls: lessons from the 
University of Jos ICT Maths initiative. [Online] Available: http://asictresearch.wordpress.com/2010/05/21 (October 2, 2013).

Madu, E.C.\& Pam, L.A. (2011). Learning Electronically in Nigeria Universities: The Example of Federal University of Technology, Minna, Nigeria. Journal of Emerging Trends in Computing and Information Sciences, 2(12), 696-700.

Mogire, M. A., \& Oboko, R. (2013). Context aware framework to support formal ubiquitous learning. International Journal of Societal Applications of Computer Science, 2(2), 248-254.

Ogboru, I. (2008). Educational policy and standards: a key to productive a productive economy. A paper presented at the national conference on improving educational standards in Nigeria: perspectives, challenges and strategies organized by department of arts and social science education, faculty of education, University of Jos, 26th - 30th, October.

Ogbuju, E., Mbanusi, C., Chukwu, P., \& Onyesolu, M.O. (2012). E-learning system: educational content delivery through mobile phones. International Journal of Emerging Trends and Technology in Computer Science, 1(2),101-106.

Olakulehin, F. K. (2007). Information and communication technologies in teacher training and professional development in Nigeria. Turkish Online Journal of Distance Education, 8(1), 133-142.

Pyramid Research Report (2010). The Impact of mobile services in Nigeria. [Online] Available: www.pyramidresearch.com (August 23, 2013).

Rieber, L.P. (2001). Designing learning environments that excite serious play. [Online] Available: http://www.nowhereroad.com (September 6, 2013).

Tan, Q., Zhang, X., Kinshuk \& Mc-Greal, R. (2011). The 5R Adaptation Framework for Location-Based Mobile Learning Systems. [Online] Available: http://mlearn.bnu.edu.cn/source/ten_outstanding_papers (August 26, 2013).

Tella, A. (2011). Availability and use of ICT in South-Westen Nigeria Colleges of education. International Multidisciplinary Journal, Ethopia, 5(5), 315-331.

Traxler, J. (2011). Mobiles and education in Africa - a sustainable and appropriate ecology. [Online] Available: http://utlo.ukzn.ac.za (September 13, 2013).

Trayek, F.A. \& Hassan, S.S.S. (2013). Attitude towards the use of learning management system among university students. Turkish online Journal of Distance Education, 14(3), 91-103.

Utulu, Sc, \& Alonge, A. (2012). Use of mobile phones for project-based learning by undergraduate students of Nigerian private universities. International Journal of Education and Development using Information and Communication Technology, 8(1), 4-15.

Valk, J. H., Rashid, A.T., \& Elder, L. (2010). Using mobile phones to improve educational outcomes - An analysis of evidence from Asia. The International Review of Research in Open and Distance Learning, 11, 117 - 117.

Warger, T., Serve, E., \& Dobbing, G. (2009). Learning environments: where space, technology and culture converge. [Online] Available: http://net.educause.edu (September 6, 2013).

Warschauer, M. (2011). Tablet computers in education. Eventually tablets will facilitate more personalized and interactive learning. [Online] Available: https://edutechdebate.org/tablet-computers- in-education (September 19, 2013).

Wen, J., Cheng, K., Chen, C. \& Hsieh, Y. (2013). A study on the application of ubiquitous learning environment to English learning in elementary schools. Universal Journal of Education and General Studies, 2(2), 53-65.

Wokocha, C.M. \& Adebayo, E.I. (2012). A Guide to establishing management information system in tertiary institutions in Nigeria. African Journal of Basic and Applied Sciences, 4(3), 83-88.

Yaradua Foundation Report (2013). Mobile learning pilot project in Nigeria. [Online] Available: www.yaeaduacentre.org (August 23, 2013). 